\title{
Use of probiotics to replace antibiotics for broilers
}

\section{Ricardo Vianna Nunes ${ }^{1}$, Carina Scherer ${ }^{1}$, Paulo Cesar Pozza², Cinthia Eyng², Luís Daniel Giusti Bruno ${ }^{1}$, Flávio Medeiros Vieites ${ }^{3}$}

\footnotetext{
${ }^{1}$ Programa de Pós-graduação em Zootecnia, Centro de Ciências Agrárias, Universidade Estadual do Oeste do Paraná, Rua Pernambuco, 1777, 85960-000, Marechal Cândido Rondon, Paraná, Brazil.

2 Programa de Pós-Graduação em Zootecnia, Universidade Estadual de Maringá, Maringá, Paraná, Brazil.

${ }^{3}$ Programa de Pós-Graduação em Ciência Animal, Universidade Federal do Mato Grosso, Rondonópolis, Mato Grosso, Brazil.
}

\begin{abstract}
This study was carried out to evaluate the effect of supplementation of probiotics (Lactobacillus acidophilus, Enterococcus faecium and Bifidubacterium bifidum) and antibiotics (flavomicina and staquinol) on diets for broilers from 1 to 42 days of age, reared in clean (new litter) and challenged (reused litter) environments. A total of 768 one-day-old male broilers of the Cobb 500 strain were distributed in a completely randomized design in a $2 \times 4$ factorial arrangement ( 2 litter types $\times 4$ diets), totaling eight treatments with eight replications and 16 poultry per experimental unit. The results of performance and carcass characteristics were submitted to analysis of variance using the Studen Newman Keuls test at 0.05 probability. In the period of 1-21 days of age, the supplementation with probiotics for poultry raised in the new litter reduced feed intake, whereas in those raised in reused litter, the diet free of growth promoter showed a lower consumption. Poultry from 1 to 42 days raised in new litter had lower feed intake when supplemented with probiotics. Other results of performance and carcass yield were not affected. For the poultry raised in reused litter, the use of probiotics resulted in lower thigh yield and higher liver yield. The use of different growth promoters in feed for broilers does not influence the performance of poultry raised in new or reused litter. The use of probiotic promotes lower feed intake without compromising the performance, regardless of the type of litter used, demonstrating the feasibility of using this product as substitute for antibiotics.
\end{abstract}

Key Words: antibiotics, carcass, performance, poultry litter, probiotic

\section{Introduction}

Growth promoters are the main additives used in the poultry feed; they are responsible for improvement in animal productivity, especially in the early stages of rearing. The majority are antibacterial products used in sub-therapeutic doses for almost the whole life of the animal, respecting only the withdrawal period before slaughter (Lorençon et al., 2007).

However, restrictions on the use of antibiotics, imposed by the European Union from January 2006, coupled with consumer demand for products free of antimicrobial residues and the concern related to the development of crossbacterial resistance among humans, have led producers and researchers to find alternatives to the usual growthpromoting agents, which, according to Corrêa et al. (2003), should not reduce the levels of productivity achieved by the poultry farmers.

Probiotics are products consisting of live microorganisms which beneficially influence the host by improving the intestinal microbial balance (Fuller, 1989). These products may contain bacteria well known and quantified or undefined bacterial cultures, generally composed of one or more of the following microorganisms: Lactobacillus, Streptococcus, Bifidobacterium, Bacillus or yeasts (Mulder, 1991).

According to Traldi et al. (2007), probiotics can improve the utilization of food and thereby reduce nutrient excretion. Furthermore, there is a tendency to increase the use of probiotics in diets for animals, which is a more reasonable option, since they do not leave residues in the environment, in the animal body and do not cause crossresistance in men compared with antibiotics (Nepomuceno \& Andreatti, 2000).

Many studies have been conducted to evaluate the replacement of antibiotics by probiotics in poultry; however, the sanitation challenge of poultry facilities is poorly evaluated, often using new litter for these experiments.

In this context, this study was conducted in order to evaluate the effect of using growth promoters (antibiotics and probiotics) in diets on performance and carcass characteristics of broilers from 1 to 42 days raised in new or reused litter. 


\section{Material and Methods}

The experimental poultry house was divided into 48 pens with dimensions $1.30 \times 1.35 \mathrm{~m}, 1.755 \mathrm{~m}^{2}$ total area, consisting of an infrared lamp (250 watts) for heating the poultry, tubular-type feeders with capacity for $20 \mathrm{~kg}$ feed and nipple-type drinkers, providing at least three nozzles per box. The poultry house had ventilation fans and spraying system for temperature control.

A total of 768 male broilers of the Cobb 500 strain from 55 -week-old age breeders were used. The poultry were vaccinated at the hatchery against Marek's disease, Avian Bouba, Infectious Bronchitis and Gumboro.

The experimental design was completely randomized, in a $2 \times 4$ factorial arrangement - two types of litter (new and reused) and four different growth promoters (probiotics and antibiotics) -, totaling eight treatments distributed into eight replications with 16 poultry per experimental unit. The reused litter was used in two other flocks. The treatments were distributed as follows: treatment 1 - diet without supplementation of growth promoter in new litter; treatment 2 - diet without supplementation of growth promoter in reused litter; treatment 3 - diet supplemented with probiotic at the ratio of $2 \mathrm{~kg} / \mathrm{t}$ for 1 to 42 days of age in new litter; treatment 4 - diet supplemented with probiotic at the ratio of $2 \mathrm{~kg} / \mathrm{t}$ for 1-42 days of age in reused litter; treatment 5 - diet supplemented with probiotic in the proportion of $2 \mathrm{~kg} / \mathrm{t} 1-42$ days of age and antibiotics up to 35 days of age on new litter; treatment 6 - diet supplemented with probiotic at the ratio of $2 \mathrm{~kg} / \mathrm{t}$ for 1 to 42 days of age and antibiotics of up to 35 days of age in reused litter; treatment 7 - diet supplemented with antibiotics for 1-35 days of age and diet without growth promoter for 36 to 42 days of age in a new litter; and treatment 8 - diet supplemented with antibiotics for 1-35 days of age and diet without growth promoter for 36 to 42 days of age in reused litter.

Every $1000 \mathrm{~g}$ of probiotic contained $3.5 \times 10^{11} \mathrm{cfu}$ of Lactobacillus acidophilus, $3.5 \times 1011 \mathrm{cfu}$ of Enterococcus faecium, and $3.5 \times 10^{11} \mathrm{cfu}$ Bifidobacterium bifidum, added in the diet at a rate of $2 \mathrm{~kg} / \mathrm{t}$ for the period of 1 to 42 days of age. The antibiotics used consisted of flavomicin and staquinol, added to the diets at the ratio of 0.004 to $0.003 \mathrm{~kg} / \mathrm{t}$, respectively, in the period of 1-35 days of age. Supplementation of growth promoters was added in replacement to the inert material in the feed.

Experimental diets (Table 1) were based on corn, soybean meal, according to feed compositions and nutritional requirements proposed by Rostagno et al. (2000), for periods from 1 to 21 days (initial), 22 to 35 days (growth) and 36-42 days of age (finishing).
Initially, birds were weighed and randomly distributed among experimental units. The pens treated with reused litter had a $1 \mathrm{~cm}$ layer of new sawdust added.

Mortality was recorded daily for correction of feed intake, according to Sakomura \& Rostagno (2007). Temperatures (minimum and maximum) and relative humidity of the poultry house were measured daily in the morning and afternoon. Throughout the experimental period, the water and feed were supplied ad libitum.

At 21 and 42 days of age, all poultry and noncosumed feed were weighed to calculate the performance parameters such as feed intake (FI), weight gain (WG) and feed conversion (FC). The data obtained were used to calculate the productive efficiency index (PEI), according to Gomes et al. (1996).

To evaluate the carcass yield of broilers at 42 days of age, two poultry per experimental unit, of average weight (10\% above or below average) were kept fasted for 6 hours and slaughtered. After bleeding, birds were plucked and eviscerated. The hot carcass was weighed and sent to

Table 1 - Proximate chemical composition of experimental diets

\begin{tabular}{|c|c|c|c|}
\hline \multirow{2}{*}{ Ingredients, $\mathrm{g} / \mathrm{kg}$} & \multicolumn{3}{|c|}{ Phase (days) } \\
\hline & 1 to 21 & 22 to 35 & 36 to 42 \\
\hline Corn & 548.00 & 587.79 & 619.37 \\
\hline Soybean meal & 374.61 & 330.52 & 299.72 \\
\hline Soybean oil & 32.89 & 40.50 & 42.52 \\
\hline Limestone & 10.55 & 9.99 & 9.66 \\
\hline Dicalcium phosphate & 18.27 & 16.44 & 15.17 \\
\hline Salt & 4.53 & 3.82 & 3.85 \\
\hline L-lysine $\mathrm{HCl}(78 \%)$ & 1.16 & 1.25 & 1.32 \\
\hline DL-methionine (99\%) & 2.19 & 1.89 & 1.69 \\
\hline Antioxidant (BHT) & 0.20 & 0.20 & 0.20 \\
\hline $60 \%$ Choline chloride & 0.60 & 0.60 & - \\
\hline Anticoccidial (salinomycin) & 0.50 & 0.50 & - \\
\hline Mineral supplement ${ }^{1}$ & 0.50 & 0.50 & 0.50 \\
\hline Vitamin supplement $^{2}$ & 1.00 & 1.00 & 1.00 \\
\hline Inert & 2.50 & 2.50 & 2.50 \\
\hline Adsorbent $^{3}$ & 2.50 & 2.50 & 2.50 \\
\hline Total (g) & 1.000 & 1.000 & 1.000 \\
\hline \multicolumn{4}{|l|}{ Calculated values } \\
\hline Metabolizable energy (kcal/kg) & 3.000 & 3.100 & 3.150 \\
\hline Crude protein $(\mathrm{g} / \mathrm{kg})$ & 214.00 & 197.90 & 186.90 \\
\hline Calcium (g/kg) & 9.63 & 8.86 & 8.35 \\
\hline Available phosphorus (g/kg) & 4.53 & 4.14 & 3.87 \\
\hline Sodium (g/kg) & 2.22 & 1.92 & 1.92 \\
\hline Potassium (g/kg) & 8.54 & 7.84 & 7.37 \\
\hline Digestible lysine (g/kg) & 11.48 & 10.51 & 9.85 \\
\hline Digestible methionine $(\mathrm{g} / \mathrm{kg})$ & 5.24 & 4.74 & 4.40 \\
\hline Digestible met. + cys. (g/kg) & 8.12 & 7.46 & 7.02 \\
\hline Digestible threonine (g/kg) & 7.38 & 6.80 & 6.40 \\
\hline Digestible tryptophan (g/kg) & 2.50 & 2.26 & 2.09 \\
\hline \multicolumn{4}{|c|}{$\begin{array}{l}\text { BHT - butylated hydroxytoluene. } \\
{ }^{1} \text { Assurance levels per kg of product: } \mathrm{Fe}-100 \mathrm{~g} ; \mathrm{Cu}-16 \mathrm{~g} \text {; Mn - } 150 \mathrm{~g} ; \mathrm{Zn}-100 \mathrm{~g} \text {; } \\
\mathrm{I}-1.5 \mathrm{~g} \text {. } \\
{ }^{2} \text { Assurance levels per kg of product: vit. A - } 8,000,000 \mathrm{IU} \text {; vit. } \mathrm{D}_{3}-2,000,000 \mathrm{IU} \text {; } \\
\text { vit. E - } 15,000 \mathrm{mg} \text {; vit. } \mathrm{B}_{1}-1.8 \mathrm{~g} \text {; vit. } \mathrm{B}_{2}-6.0 \mathrm{~g} \text {; vit. } \mathrm{B}_{6}-2.8 \mathrm{~g} \text {; vit. } \mathrm{B}_{12}-12,000 \mathrm{mcg} \text {; } \\
\text { pantothenic acid - } 15 \mathrm{~g} \text {; vit. } \mathrm{K}-1.8 \mathrm{~g} \text {; folic acid - } 1.0 \mathrm{~g} \text {; nicotinic acid - } 40.0 \mathrm{~g} \text {; Se - } 0.3 \mathrm{~g} \text {. } \\
{ }^{3} 80 \% \text { Clinoptilolite-heulandite. }\end{array}$} \\
\hline
\end{tabular}


evaluation of the cuts yields (breast, thigh, drumstick and wing) relative to the weight of the eviscerated carcass. The abdominal fat, comprised of adipose tissue around the cloaca, gizzard, proventriculus and adjacent abdominal muscles, was weighed and calculated in relation to the weight of the eviscerated carcass, as well as heart and liver.

The results of performance and carcass characteristics were analyzed using software SAEG (Statistical Analysis System, version 8.0), performing analysis of variance and using the SNK test at 0.05 probability.

\section{Results and Discussion}

The maximum and minimum average temperatures recorded inside the shed during the entire experimental period were 32.23 and $24.27{ }^{\circ} \mathrm{C}$, respectively (Table 2). The average relative humidity recorded during the period was $58.34 \%$.

There was no interaction $(\mathrm{P}>0.05)$ between the growth promoters and the type of litter used in the final weight, weight gain, feed conversion and viability of poultry in the period of 1-21 days of age (Table 3). Analyzing the use of growth promoters for each type of litter used, there were no significant differences $(\mathrm{P}>0.05)$ in performance variables in the period of 1-21 days of age.

Table 2 - Mean values of temperature and relative humidity (RH; maximum and minimum) observed during the experimental period

\begin{tabular}{lcccccc}
\hline \multirow{2}{*}{$\begin{array}{l}\text { Period } \\
\text { (days) }\end{array}$} & \multicolumn{4}{c}{ Temperature $\left({ }^{\circ} \mathrm{C}\right)$} & \multicolumn{2}{c}{ RH (\%) } \\
\cline { 2 - 5 } & \multicolumn{2}{c}{ Maximum } & \multicolumn{2}{c}{ Minimum } & & \\
\cline { 2 - 5 } & $8 \mathrm{~h} 00$ & $18 \mathrm{~h} 00$ & $8 \mathrm{~h} 00$ & $18 \mathrm{~h} 00$ & $8 \mathrm{~h} 00$ & $18 \mathrm{~h} 00$ \\
\hline 1 to 7 & 32.43 & 34.01 & 27.99 & 28.56 & 54.75 & 43.75 \\
8 to 21 & 30.21 & 35.33 & 23.54 & 25.36 & 69.57 & 57.14 \\
22 to 35 & 28.36 & 34.32 & 21.22 & 22.13 & 70.52 & 51.73 \\
36 to 42 & 29.14 & 34.06 & 21.49 & 23.89 & 70.43 & 48.86 \\
\hline
\end{tabular}

In this research, although a sanitation challenge was induced by the use of reused litter in some treatments, there was no effect $(\mathrm{P}>0.05)$ from growth promoters on the final weight, weight gain and feed conversion. This result is probably related to the low sanitation challenge, which may have been insufficient to compromise the poultry performance.

According to Ferreira \& Kussakawa (1999), probiotics do not always have positive outcomes in relation to weight gain and feed conversion of poultry; this is due to several variants, such as poultry health, duration of poultry house downtime and environmental contamination levels. Furthermore, there is a need for probiotics at appropriate concentrations and sufficiently stable, both during storage and administration to poultry. Thus, the effectiveness of the product is strictly dependent on characteristics and quantity of microorganism strains used in the probiotic preparation (Tournut, 1998); it is very difficult to draw a parallel between studies and compare the results.

Lorençon et al. (2007), evaluating the use of growth promoters for broilers, found no effect from different probiotics and antibiotics on performance of broilers during 1-21 days of age. Likewise, Correa et al. (2003), working on diets containing probiotics and antibiotics, found no differences in weight gain or feed conversion in the period of 1-20 days.

Similar results were verified by Pelicano et al. (2004), who evaluated the effect of different growth promoters and found no significant differences on weight gain and feed conversion of broilers during 1-21 days of age. Similarly, Takahashi et al. (2005) found no effect of using probiotics and prebiotics on the final weight, weight gain and feed conversion of broilers during 1-35 days of age. Rocha et al. (2010) also showed no differences in performance variables according to the use of prebiotics, probiotics and organic acids in diets for broilers in the period of 8-21 days of age.

Table 3 - Performance of broiler chickens aged 1-21 days, fed diets with different growth promoters

\begin{tabular}{|c|c|c|c|c|c|c|}
\hline \multirow{2}{*}{ Parameters } & \multirow{2}{*}{ Litter type } & \multicolumn{4}{|c|}{ Treatments } & \multirow{2}{*}{$\mathrm{CV}(\%)$} \\
\hline & & Promoter-free & Probiotics & Probiotics + antibiotics & Antibiotics & \\
\hline \multirow[t]{2}{*}{ Final weight ${ }^{\text {ns }}(\mathrm{g})$} & $\mathrm{New}^{\mathrm{ns}}$ & 922.51 & 881.04 & 896.38 & 911.04 & 3.28 \\
\hline & Reused $^{\mathrm{ns}}$ & 907.37 & 914.90 & 929.56 & 931.79 & 2.77 \\
\hline \multirow[t]{2}{*}{ Weight gain ${ }^{\text {ns }}(\mathrm{g})$} & $\mathrm{New}^{\mathrm{ns}}$ & 877.11 & 835.64 & 850.94 & 865.73 & 3.46 \\
\hline & Reused $^{\text {ns }}$ & 861.97 & 869.50 & 884.24 & 886.47 & 2.91 \\
\hline \multirow[t]{2}{*}{ Feed intake* $(\mathrm{g})$} & New & $1098.64 \mathrm{aA}$ & $1044.03 \mathrm{bB}$ & $1076.60 \mathrm{aA}$ & $1104.76 \mathrm{aA}$ & 2.50 \\
\hline & Reused & $1062.87 \mathrm{bB}$ & $1077.56 \mathrm{abA}$ & $1106.80 \mathrm{abA}$ & $1107.13 \mathrm{abA}$ & 2.63 \\
\hline \multirow[t]{2}{*}{ Feed conversion $^{\text {ns }}(\mathrm{g} / \mathrm{g})$} & New ${ }^{\text {ns }}$ & 1.25 & 1.25 & 1.27 & 1.28 & 2.23 \\
\hline & Reused $^{\mathrm{ns}}$ & 1.23 & 1.24 & 1.25 & 1.25 & 2.23 \\
\hline \multirow[t]{2}{*}{ Viability $^{\mathrm{ns}}(\%)$} & $\mathrm{New}^{\mathrm{ns}}$ & 98.96 & 100 & 97.92 & 98.96 & 3.09 \\
\hline & Reused $^{\mathrm{ns}}$ & 96.88 & 98.96 & 98.96 & 97.92 & 3.09 \\
\hline
\end{tabular}


Moreover, Silva et al. (2011), using various growth promoter additives in broilers, observed that poultry fed the diet with probiotics and synbiotics showed higher weight gain during 1-21 days of age. Boratto et al. (2004), evaluating the use of antibiotics, probiotics and homeopathy in the diet, found higher weight gain for broilers treated with antibiotics and probiotics during 1-21 days of age.

Feed intake in the period of 1-21 days showed interaction between growth promoters and the type of litter used. Supplementation with probiotics for poultry housed in new litter promoted lower consumption compared with the other treatments. In the poultry housed in reused litter, the diet without growth promoter promoted the lowest feed intake.

The effect of probiotics on feed intake of poultry raised in a new litter can be a consequence of rearing poultry in optimum prophylactic condition, therefore not constituting a challenging situation. Thus, the intestinal flora would be unbalanced with the supplementation of microorganisms present in the probiotics at amounts usually above that found in the digestive tract and, thereby, the microorganisms become an "infective" agent, causing changes in the metabolism and interfering with the feed intake of poultry.

Loddi et al. (2000a), in a study to evaluate the use of probiotics and antibiotics on the performance of broilers, found similar results, in which the poultry fed the diet supplemented with probiotics had lower feed intake in the initial rearing phase. Correa et al. (2003) found no differences on feed intake of broilers fed diets supplemented with probiotics and antibiotics in the initial rearing phase. Likewise, Loddi et al. (2000b), studying the isolated or combined action of probiotics and antibiotics as growth promoters, found no differences in feed intake by poultry in the initial rearing phase. Faria et al. (2009), in a study evaluating the use of probiotics as alternative to using antibiotics as growth promoters for broilers, also found no effect on feed intake during the period of 1-21 days. Silva et al. (2011) obtained better result with antibiotic supplementation in the diets of broilers from 1 to 21 days of age.

The poultry feed conversion was not influenced $(\mathrm{P}>0.05)$ by supplementation with different growth promoters, or by the litter type used in the period of 1-21 days of age. The use of different growth promoter additives did not influence the results of feed conversion of chicks in the initial rearing phase in the studies conducted by Silva et al. (2011), Rocha et al. (2010), Faria et al. (2009), Lorençon et al. (2007), Takahashi et al. (2005) and Pelicano et al. (2004). However, Maiorka et al. (2001), evaluating the effects of substitution of antibiotics by prebiotics, probiotics and synbiotics in diets for broilers in the period of 1-21 days of age, observed better feed conversion in poultry fed probiotics.

The different growth promoters evaluated as well the litter type used had no consistent effect on the viability of poultry in period of 1-21 days of age. Several authors (Silva et al., 2011; Lorençon et al., 2007; Takahashi et al., 2005; Pelicano et al., 2004), evaluating the use of different growth promoters, showed similar results and found no differences in mortality rates and viability of broilers in the initial rearing phase.

There was no interaction between the growth promoters and the type of litter used on the performance parameters of broilers at 1-42 days of age (Table 4).

Analyzing the use of growth promoters in each type of litter used, there was effect only on the feed intake of poultry reared in new litter, which was lower for poultry fed a diet supplemented with probiotics. Similar to that verified in the present study, Loodi et al. (2000a) observed lower feed intake in poultry fed diets supplemented with

Table 4 - Performance of broilers aged from 1 to 42 day fed diets containing different growth promoters

\begin{tabular}{|c|c|c|c|c|c|c|}
\hline \multirow{2}{*}{ Parameters } & \multirow{2}{*}{ Litter type } & \multicolumn{4}{|c|}{ Treatments } & \multirow{2}{*}{$\mathrm{CV}(\%)$} \\
\hline & & Promoter-free & Probiotics & Probiotics + antibiotics & Antibiotics & \\
\hline \multirow[t]{2}{*}{ Final weight $^{\text {ns }}(\mathrm{g})$} & $\mathrm{New}^{\mathrm{ns}}$ & 2555 & 2466 & 2544 & 2518 & 2.72 \\
\hline & Reused $^{\mathrm{ns}}$ & 2601 & 2523 & 2577 & 2596 & 3.13 \\
\hline \multirow[t]{2}{*}{ Weight gain ${ }^{\mathrm{ns}}(\mathrm{g})$} & $\mathrm{New}^{\mathrm{ns}}$ & 2510 & 2420 & 2499 & 2472 & 2.77 \\
\hline & Reused $^{\text {ns }}$ & 2555 & 2478 & 2532 & 2550 & 3.19 \\
\hline \multirow[t]{2}{*}{ Feed intake $(\mathrm{g})$} & New & $4092 a$ & $3928 b$ & $4103 a$ & $4089 a$ & 2.66 \\
\hline & Reused & 4143 & 4038 & 4126 & 4156 & 2.83 \\
\hline \multirow[t]{2}{*}{ Feed conversion $^{\text {ns }}(\mathrm{g} / \mathrm{g})$} & New $^{\text {ns }}$ & 1.63 & 1.62 & 1.64 & 1.65 & 2.05 \\
\hline & Reused $^{\text {ns }}$ & 1.62 & 1.64 & 1.63 & 1.63 & 1.56 \\
\hline \multirow[t]{2}{*}{ Viability $^{\text {ns }}(\%)$} & $\mathrm{New}^{\mathrm{ns}}$ & 97.92 & 94.79 & 96.88 & 95.83 & 3.09 \\
\hline & Reused $^{\mathrm{ns}}$ & 92.71 & 98.96 & 97.92 & 94.79 & 3.09 \\
\hline \multirow[t]{2}{*}{ Productive efficiency indexe $\mathrm{e}^{\mathrm{ns}}$} & $\mathrm{New}^{\mathrm{ns}}$ & 359 & 337 & 352 & 341 & 7.56 \\
\hline & Reused $^{\text {ns }}$ & 348 & 355 & 363 & 353 & 6.42 \\
\hline
\end{tabular}

$\mathrm{CV}$ - coefficient of variation; ns - not significant.

Means followed by different lowercase letters in the same row differ by the SNK test at 5\% probability. 
probiotics compared with those fed a diet without probiotic in the period of 1-42 days.

Evaluating the use of inulin and probiotics in broilers, Silva et al. (2011) found no effect of using these growth promoters on the final weight, weight gain, feed intake and feed conversion of broilers in the period of 1-42 days of age. Similar results were observed by Rocha et al. (2010), who evaluated the use of different growth promoters in feed for broiler chickens from 22 to 43 days of age and found no effect on the final weight, weight gain and feed intake. However, the authors found better feed conversion in the birds that received the combined diet containing prebiotics and organic acids (fumaric and propionic), while the probiotic supplementation in diets resulted in lower feed conversion.

The use of different probiotics in diets for broilers evaluated by Lorençon et al. (2007) also did not affect the performance of poultry aged from 1 to 42 days. Likewise, Pelicano et al. (2004) observed no significant differences in weight gain, feed intake and feed conversion of broilers fed diets with different probiotics in the period of 1-45 days of age. Different antibiotics and probiotics did not affect the performance variables of the broilers aged from 1 to 42 days studied by Faria et al. (2009) and Boratto et al. (2004).

The different growth promoters evaluated as well the type of litter used had no consistent effect on the viability of poultry aged from 1 to 42 days. The use of different growth promoters studied by Silva et al. (2011), Faria et al. (2009), Lorençon et al. (2007), Takahashi et al. (2005) and Pelicano et al. (2004) did not influence the viability and mortality of broiler chickens in the finishing phase.

The productive efficiency index (PEI) of broilers was not influenced by the use of different growth promoters and the type of litter used. Similar results were reported by Silva et al. (2011), Faria et al. (2009) and Lorençon et al. (2007), who found no effect of using different antibiotics and probiotics on PEI for broilers. Likewise, Brito et al. (2005), providing poultry with diets supplemented with Olaquindox (antibiotic) or probiotics based on Bacillus subtilis in diets, reported no significant effects on PEI.

There was no interaction between the growth promoters and type of litter used on carcass yield and cuts of poultry at 42 days of age (Table 5). Analyzing the use of growth promoters in each litter type, it was observed that the use of probiotics resulted in lower thigh yields and higher liver/ body ratio for poultry reared in reused litters. The other cuts as well as the percentage of abdominal fat did not have their yields affected by the factors studied in this research.

The increase in liver size of poultry housed in reused litter fed on diets containing probiotics may be the result of the health challenge to which they were subjected, in which the growth promoter addressed was not effective for combating the action of microorganisms in the litter. In a study evaluating the use of antibiotics, probiotics and homeopathy in broiler chickens raised in a clean environment, inoculated or not with Escherichia coli, Boratto et al. (2004) found increased liver size of poultry reared in environment inoculated with bacteria, which may be related to the neutralization of toxic substances produced from the metabolic activity of intestinal bacteria, which requires a constant energy expenditure made by the liver for detoxification inducing the hypertrophy of hepatocytes.

Silva et al. (2011), Faria et al. (2009) and Lorençon et al. (2007), evaluating the use of different growth promoters for broilers, observed no effect on any variable of carcass yield, or in the percentage of abdominal fat at 42 days of

Table 5 - Carcass yield and cuts, percentage of liver and abdominal fat of broilers aged 42 days

\begin{tabular}{|c|c|c|c|c|c|c|}
\hline \multirow{2}{*}{ Parameters } & \multirow{2}{*}{ Litter type } & \multicolumn{4}{|c|}{ Treatments } & \multirow{2}{*}{$\mathrm{CV}(\%)$} \\
\hline & & Promoter-free & Probiotics & Probiotics + antibiotics & Antibiotics & \\
\hline \multirow[t]{2}{*}{ Carcass $^{\text {ns }}(\%)$} & $\mathrm{New}^{\mathrm{ns}}$ & 67.12 & 65.50 & 65.33 & 66.38 & 3.83 \\
\hline & Reused $^{\mathrm{ns}}$ & 67.18 & 66.89 & 66.75 & 67.16 & 3.80 \\
\hline Breast $^{\text {ns }}(\%)$ & Reused $^{\text {ns }}$ & 35.98 & 36.20 & 35.76 & 36.30 & 4.40 \\
\hline \multirow[t]{2}{*}{$\operatorname{Thigh}^{\text {ns }}(\%)$} & $\mathrm{New}^{\mathrm{ns}}$ & 16.28 & 16.37 & 16.19 & 15.95 & 7.97 \\
\hline & Reused $^{\mathrm{ns}}$ & 16.01 & 16.20 & 15.79 & 16.04 & 5.32 \\
\hline \multirow[t]{2}{*}{ Wing $^{\text {ns }}(\%)$} & $\mathrm{New}^{\mathrm{ns}}$ & 11.57 & 11.92 & 11.81 & 12.07 & 5.82 \\
\hline & Reused $^{\mathrm{ns}}$ & 11.89 & 11.65 & 11.92 & 11.38 & 7.34 \\
\hline \multirow[t]{2}{*}{ Heart $^{\text {ns }}(\%)$} & $\mathrm{New}^{\mathrm{ns}}$ & 0.58 & 0.65 & 0.62 & 0.61 & 15.24 \\
\hline & Reused $^{\mathrm{ns}}$ & 0.65 & 0.61 & 0.65 & 0.65 & 18.19 \\
\hline \multirow[t]{2}{*}{ Liver (\%) } & $\mathrm{New}^{\mathrm{ns}}$ & 2.70 & 2.95 & 2.90 & 2.77 & 13.45 \\
\hline & Reused & $2.87 \mathrm{ab}$ & $3.03 \mathrm{a}$ & $2.72 b$ & $2.76 \mathrm{~b}$ & 8.64 \\
\hline
\end{tabular}

CV - coefficient of variation; ns - not significant.

Means followed by different lowercase letters in the same row differ by the SNK test at $5 \%$ probability. 
age. However, Rocha et al. (2010) observed higher breast yield in broilers aged 43 days fed a diet supplemented with a mixture of probiotics, while the diet without growth promoter had lower yield of this cut. The authors observed no effect from using growth promoters on the thigh yield.

Loddi et al. (2000a) observed interaction between probiotics and antibiotics for the carcass yield, obtaining the highest value of this variable when there was association between the use of the two growth promoters. For cut yields, the authors found no effect of growth promoters; however, the total amount of edible offal and gizzard was higher for poultry fed diets supplemented with probiotics. Abdominal fat was not influenced by the use of growth promoters.

According to Faria et al. (2009), the different responses to the use of probiotics for broiler chickens may be due to factors such as different concentrations and micro-organisms used, the animal health, diets and facilities, temperature, stocking density, strain, sex, nutritional levels employed, among others. Thus, it is important that more research be conducted with the proper control of the aforementioned factors to obtain conclusive evidence, which will allow the safe recommendation of probiotics to the poultry industry.

A point to be emphasized is that the expected advantages of using probiotics in field are greater than those found in experimental conditions, since, for all practical purposes, the poultry farmer has the litters reused with several flocks. Thus, it is important to conduct further research on conditions that represent the real health challenge of poultry farms, thus enabling the demonstratation of the effectiveness of probiotics for poultry productivity.

\section{Conclusions}

The use of probiotics and antibiotics in feed for broiler chickens does not affect the performance of poultry reared in new or reused litter. The use of probiotics promotes reduced feed intake without compromising performance, regardless of the type of litter used.

\section{References}

BORATTO, A.F.; LOPES, D.C.; OLIVERIA, R.F.M. et al. Uso de antibiótico, de probiótico e de homeopatia, em frangos de corte criados em ambiente de conforto, inoculados ou não com Escherichia coli. Revista Brasileira de Zootecnia, v.33, n.6, p.1477-1485, 2004.

BRITO, A.B.; NADJA S.M.L.; HENRIQUE, J.S. et al. Desempenho e digestibilidade de nutrientes para frangos alimentados com rações contendo promotor de crescimento (Olaquindox) e probiótico (Bacillus subtillis) Acta Scientiarum Animal Science, v.27, n.3, p.327-332, 2005.
CORRÊA, G.S.S.; GOMES, A.V.C.; CORRÊA, A.B. et al. Efeito de antibiótico e probiótico sobre o desempenho e rendimento de carcaça de frangos de corte. Arquivo Brasileiro de Medicina Veterinária e Zootecnia, v.55, n.4, p.467-473, 2003.

FARIA, D.E.; HENRIQUE, A.P.F.; FRANZOLINI NETO, R. et al. Alternativas ao uso de antibióticos como promotores de crescimento para frangos de corte: 1. probióticos. Ciência Animal Brasileira, v.10, n.1, p.18-28, 2009.

FERREIRA, F.A.B.; KUSSAKAWA, K.C.K. Probióticos. Biotecnologia, Ciência \& Desenvolvimento, n.8, p.40-43, 1999.

FULLER, R. Probiotics in man and animals. Journal of Applied Bacteriology, v.66, p.365-378, 1989.

GOMES, P.C.; ALBINO, L.F.T.; SILVA, M.A. Criação de frangos de corte. Viçosa, MG, ano 17, n.78, 1996. 18p. (Informe Técnico).

LODDI, M.M.; GONZALES, E.; TAKITA, T.S. et al. Uso de probiótico e antibiótico sobre o desempenho, o rendimento e a qualidade de carcaça de frangos de corte. Revista Brasileira de Zootecnia, v.29, n.4. p.1124-1131, 2000a.

LODDI, M.M.; RICHARD, N.S.; ARIKI, J. et al. Ação isolada ou combinada de antibiótico e probiótico como promotores de crescimento em rações inicais de frangos de corte. REUNIÃO ANUAL DA SOCIEDADE BRASILEIRA DE ZOOTECNIA, 2000, Viçosa, MG. Anais... Viçosa, MG: SBZ, 2000b. p.254.

LORENÇON, L.; NUNES, R.V.; POZZA, P.C. et al. Utilização de promotores de crescimento para frangos de corte em rações fareladas e peletizadas. Acta Scientiarum Animal Science, v.29, n.2, p.151-158, 2007.

MAIORKA, A.; SANTIN, E.; SUGETA, S.M. et al. Utilização de prebióticos, probióticos ou simbióticos em dietas para frangos. Revista Brasileira de Ciência Avícola, v.3, n.1, p.75-82, 2001.

MULDER, R.W.A.W. Probiotics as a tool against Salmonella contamination. World's Poultry Science Journal, v.7, n.3, p.36-37, 1991.

NEPOMUCENO, E.S.; ANDREATTI, R.L.F. Probióticos e prebióticos na avicultura. In: SIMPÓSIO DE SANIDADE AVÍCOLA, 2., 2000, Santa Maria. Anais... Concórdia: Embrapa Suínos e Aves, 2000. v.1, p.45-55.

PELICANO, E.R.L.; SOUZA, P.A.; SOUZA, H.B.A. et al. Productive traits of broiler chickens fed diets containing different growth promoters. Revista Brasileira de Ciência Avícola, v.6, n.3, p.177-182, 2004.

ROCHA, A.P.; ABREU, R.D.; COSTA, M.C.M.M. et al. Prebióticos, ácidos orgânicos e probióticos em rações para frangos de corte. Revista Brasileira de Saúde e Produção Animal, v.11, n.3, p.793-801, 2010.

ROSTAGNO, H.S.; ALBINO, L.F.T.; DONZELE, J.L. et al. Tabelas brasileiras para aves e suínos: composição de alimentos e exigências nutricionais. Viçosa, MG: Universidade Federal de Viçosa, 2000. 141p.

SAKOMURA, N.K.; ROSTAGNO, H.S. Métodos de pesquisa em nutrição para monogástricos. Jaboticabal: Funep, 2007. $283 p$.

SILVA, W.T.M.; NUNES, R.V.; POZZA, P.C. et al. Avaliação de inulina e probiótico para frangos de corte. Acta Scientiarum. Animal Sciences, v.33, n.1, p.19-24, 2011.

TAKAHASHI, S.E.; MENDES, A.A.; SALDANHA, E.S.P.B. et al Efficiency of prebiotics and probiotics on the performance, yield, meat quality and presence of Salmonella spp in carcasses of free-range broiler chickens. Revista Brasileira de Ciência Avícola, v.7, n.3, p.151-157, 2005.

TRALDI, A.B.; OLIVEIRA, M.C.; DUARTE, K.F. et al. Avaliação de probióticos na dieta de frangos de corte criados em cama nova ou reutilizada. Revista Brasileira de Zootecnia, v.36, n.3, p.660-665, 2007.

TOURNUT, J.R. Probiotes. In: REUNIÃO DA SOCIEDADE BRASILEIRA DE ZOOTECNIA, 35., 1998, Botucatu. Anais... Botucatu: SBZ, 1998. p.179-99. 